\title{
MOLLUSCICIDAL ACTIVITY OF ZINGIBER OFFICINALE AND CARICA PAPAYA ON THE EGG HATCHABILITY OF THE GOLDEN APPLE SNAIL, POMACEA CANALICULATA (GASTROPODA: AMPULIRIIDAE)
}

\author{
Hasnun Nita Ismail ${ }^{1 a^{*}}$ and Nadia Nisha Musa ${ }^{2 a}$
}

aDepartment of Biology, Faculty of Applied Sciences, University Technology of MARA Perak Branch, Tapah Campus, 35400 Tapah Road, Perak, MALAYSIA. Email: hasnunnita@uitm.edu.my ${ }^{1}$; nadianisha@uitm.edu.my ${ }^{2}$ *Corresponding author: hasnunnita@uitm.edu.my

Received: $11^{\text {th }}$ May $2020 \quad$ Accepted: $11^{\text {th }}$ Sep 2020

Published: $30^{\text {th }}$ Jun 2021

DOI: https://doi.org/10.22452/mjs.vol40no2.4

\begin{abstract}
The study was conducted to assess the effect of Zingiber officinale and Carica papaya extract on the egg hatchability of the golden apple snail, Pomacea canaliculata. This is a freshwater snail that is considered a pest in agriculture as well as natural ecosystems. In combating the population of the aforementioned pest, this study evaluates the use of plant extracts such as biomolluscicides to control the production of new hatchlings from the clusters of eggs. The egg clusters were exposed to different concentrations of Z. officinale ethanolic extract and $C$. papaya methanolic extracts $(25 \mathrm{ppm}, 50 \mathrm{ppm}, 100 \mathrm{ppm})$ using the direct single spraying method. Observation was made for a maximum of 30 days. The time taken for the eggs to hatch and the number of eggs successfully hatched were measured to reflect the potential of both extracts in affecting egg hatchability. The finding shows that the eggs hatch later when exposed to increasing concentrations ( 25 to $100 \mathrm{ppm}$ ) of $Z$. officinale extract. The number of eggs successfully hatched was significantly decreased from $86 \%$ to $9 \%$ after exposure to $25 \mathrm{ppm}$ and above. Meanwhile, the extract of $C$. papaya did not show any significant effect on both parameters for egg hatchability of $P$. canaliculata, regardless of the increase in concentration from 25 to $100 \mathrm{ppm}$. Our findings reveal that the extract of $Z$. officinale contains higher molluscicidal activity than the extract of $C$. papaya. Therefore, it has the potential to be commercialized as a biomolluscicide to control the population of golden apple snails specifically at the egg stage.
\end{abstract}

Keywords: biomolluscicide, golden apple snail, egg hatchability, ginger, papaya

\section{INTRODUCTION}

The occurrence of pest organisms in agricultural areas is always a nuisance to farmers. For instance, at rice plantations, the paddy plant suffers from various pest organisms, right from the sowing process until it is ready for harvesting. Some of the pests are manageably under control but some are still contributing to a major loss in agriculture. Not only do they cause damage to crops, but the population breeds and invades other areas of plantations rapidly. One of the pests and invasive organisms is the freshwater snail, the golden apple snail from the family of Pomacaea, which is a non-native species to our country. Not only it is a well-known pest in Malaysia, but the golden apple snail is also recorded as the most invasive species worldwide on the list of Global Invasive Species (Lowe et al., 2000). 
The introduction of Pomacea sp. in Malaysia is believed to be in the early of 1990s. In Peninsular Malaysia, they were first spotted around the tin mine areas in Puchong, Selangor and the rice fields in Kampung Pengkalan Semeling, Kedah; and in West Malaysia, around Keningau, Sabah. In the beginning, the population did not cause any problems until major damages were reported at almost all rice plantations in Malaysia by the end of the 1990s. In the review provided by Yahaya et al. (2017), he stated that the total area infested was around 17,399 ha in 2004, and that increased to almost 20,704 ha in late 2008. The total infested area during off-season in 2015 was about 1,939 ha. In 2010, costs associated with apple snail damage were estimated at RM82 million (US \$28 million). Since 2009 , following intervention measures, the data suggests a fluctuating but stable area of around 2,500 ha from 2009 until 2012. Considering the total area of rice infested in Malaysia and the two yearly planting seasons, the total loss caused is estimated to be more than US $\$ 2.63$ million per year.

In Peninsular Malaysia, the population of the golden apple snail is mainly composed of two dominant species; Pomacea maculata and Pomacea canaliculata (Arfan et al., 2014). Of the two species, $P$. maculata has been reported with widespread distribution and high abundance around 5 states of Peninsular Malaysia (Perak, Kedah, Selangor, Penang and Kelantan). However, a year after, a study by Phoong et al. (2018) with over 25 sampling sites revealed the occurrence of $P$. canaliculata within 15 sampling sites, whereas $P$. maculata was found in just 4 sampling sites around Selangor. At the northern region of Perlis and Kedah, a major distribution of $P$. canaliculata was reported by Mohd Salleh et al. (2012), while in Sabah, extensive study on the biology and ecology of $P$. canaliculata was provided by Teo (2004).
Thus far, an integrated pest management system has been employed as a control measure for snail infestation around agricultural areas. The system integrates various methods such as physical, chemical and biological measures. Physical methods are tedious and consume high manpower as the collecting of snails and picking of the eggs are done manually. The chemical method is favourable since it produces a fast knockdown effect on the snails. However, it adversely affects non-target organisms and ecosystems. It would be in one's best interest to use biological methods which are considered safer and environment-friendly to improvise the integrated pest management in agriculture. Among the most intensive areas is the research on the use of plant extracts as a biomolluscicide. In previous literature, a comprehensive review on 26 types of plant species with molluscicidal activity was provided by Marston and Hostettmann (1985). Most are non-native plant species in Malaysia and the best molluscicides should have activity at concentrations of lower than $100 \mathrm{ppm}$ and are non-toxic to other non-target organisms.

Several plant species distributed in Malaysia which showed molluscicidal activities have been reported elsewhere. These include the lemon grass, Cymbopogon citratus (Demetillo et al., 2015), Barringtonia racemosa (Musman et al., 2013), Azadirachta indica (Massaguni \& Md Latip, 2012; Massaguni \& Md. Latip, 2015), and Chromoleana odorata (Doctor, 2019). These studies tested the eggs and adult stages by determining the rate of hatchability or mortality at $50 \%$ and $90 \%$. The results varied depending on the species of the snail, solvent for extraction and exposure time. However, only $B$. racemosa and $A$. indica extracts showed toxicity at concentrations lower than $100 \mathrm{ppm}$, indicating that these extracts contain strong 
molluscicidal activities. In a study by Ramli et al. (2017), he claimed that the extract of Furcraea selloa var. marginata and spent tea leaves are potential biomolluscicides for golden apple snails, $P$. canaliculata. The study proved over $50 \%$ mortality in adult snails after 24 hours of exposure to a concentration as low as $1.00 \mathrm{ppm}$ that was applied on the snails. The same study also revealed the molluscicidal activity of water hyacinth species, Monochoria vaginalis, when $>50 \%$ mortality was observed after 36 hours of exposure. In this study, we aim to assess the effectiveness of $Z$. officinale extract and $C$. papaya extract to demonstrate molluscicidal effects, particularly on the egg stage of the $P$. canaliculata. Both herbaceous plants are uncommon around Malaysia and their ethnobotanical properties are welldocumented (Mao et al., 2019; Mahboubi, 2019; Priyadarshi \& Ram, 2018; Srivastava \& Singh, 2016). Therefore, research in identifying the use of the plants in the field of sustainable and environment-friendly agriculture needs to be exploited, particularly to reduce dependence on chemical pesticides in integrated pest management.

\section{METHODOLOGY}

\subsection{Snail collection and eggs selection}

The population of adult $P$. canaliculata has been captured around rice fields in the area of Chenderong Balai, Perak and Sungai Lampam, Perak. The species was identified based on the description provided by Arfan et al. (2014). They were transported inside a plastic container and were kept in the Plant Laboratory, Faculty of Applied Sciences, UiTM Perak Branch Tapah Campus. Rearing of the adult snails was conducted using a glass aquarium tank filled with aging tap water, with approximately 3 inches of depth from the bottom of the aquarium. The animals were fed with fresh lettuce ad libitum, and the rearing water was renewed twice a week to prevent the unfavourable smell from the decomposition of leftover food and metabolic waste of the snails. Inside of the aquarium tank, we suspended long sticks vertically from the top of the tank closure to the bottom of the aquarium. These sticks served to assist the female adults during the egg laying process at the aerial part above the water surface. Egg clusters below 24 hours old were selected as the experimental unit for further assessment.

\section{2 of plants \\ Preparation and extraction}

\subsubsection{Z. officinale}

The epidermis layers of rhizomes were peeled off and the inner part of rhizomes were cut into thin slices. The drying process was carried out under indirect sunlight until the samples of ginger were completely dry. The dried ginger slices were grounded into fine powder and soaked in ethanol overnight (1: 5). Thereafter, the mixture was filtered, and the filtrate was evaporated by using a rotary evaporator at $60^{\circ} \mathrm{C}$ until the formation of crude extracts emerged. The extract was aliquoted into a dark bottle and kept in the fridge $\left(4^{\circ} \mathrm{C}\right)$ for further experimentation.

\subsubsection{C.papaya}

The leaves of $C$. papaya were deveined and left to dry for several days. The drying process was conducted outdoors within indirect sunlight. The dried leaves were grounded into fine powder and then soaked in methanol (1:5) overnight to allow a complete extraction process. After a night, the extraction mixture was filtered and the filtrate was evaporated using a rotary evaporator at $45^{\circ} \mathrm{C}$ to obtain the crude extract of $C$. papaya leaves. The 
crude extract was transferred to a dark bottle and kept in the fridge $\left(4^{\circ} \mathrm{C}\right)$ for further experimentation.

\subsection{Assessment of crude extracts on egg hatchability}

The assessment on the molluscicidal activity of the crude extracts on the eggs of $P$. canaliculata was determined using a spot spraying method, as adopted by Musman et al. (2013) and Sisa et al. (2016). All the crude extracts were left in ambient temperature before the assessment on egg hatchability. Thereafter, each of the extracts were diluted with distilled water to make up for 25, 50 and $100 \mathrm{ppm}$. Then, the diluted solutions were each transferred into a small spray bottle (total volume $=50 \mathrm{~mL}$ ) and were then ready for spraying assessment.

Egg clusters of less than 24 hours old were collected and the clusters were separated individually into a small plastic cup half-filled with soil. The clusters were divided into $2 \times 3$ units representing the experimental units for 2 different extracts versus 3 different concentrations. Each unit of experiment was set up in triplicates. The egg clusters were sprayed with up to a maximum of $5 \mathrm{~mL}$ of the plant extracts. During the spot spraying, no excess extract liquid was allowed to drip off and all egg surfaces must be in contact with the extract spray. The spraying process was continued the next day until all of the total $5 \mathrm{~mL}$ extract was utilized. A set of experiment where the egg clusters (triplicate) were sprayed with distilled water was employed as a control experiment in both plant extracts assessments.

The egg hatchability was assessed through the length of time taken for the embryos to fully develop inside of the eggs (hatching time; days) and the number of hatchlings successfully emerged from the eggs ( $\%$ of hatching success). Observation was conducted for a maximum of 30 days.
Any eggs that failed to develop thereafter, were considered unsuccessful in terms of hatchability.

\subsection{Data analysis}

All the data recorded for hatching time (days) and hatching success (\%) were analysed separately based on the type of plant extracts. Analysis was conducted using the statistical software by IBM SPSS ver. 20. Before the parametric test, the data was explored for normality assumption and homogeneity of variances. All data met the assumptions for ANOVA except data related to hatching success which was logtransformed to meet the assumption for homogeneity of variances.

One-way ANOVA was employed to find the differences between groups. Posthoc test was performed using the Tukey test. All the analysis was set up with a significant level of $p<0.05$.

\section{RESULTS}

\subsection{Z. officinale}

Our findings indicated that the hatching time increased significantly with increasing concentrations of the extracts from 25 to 100 ppm (One-way ANOVA; $p$ $<0.05$; Table 1.0). An increase from 25 to $50 \mathrm{ppm}$ did not differ significantly but an increase of up to $100 \mathrm{ppm}$ showed a significant difference in hatching time. The control experiment resulted with no significant difference with $25 \mathrm{ppm}$, but differed significantly with 50 and 100 ppm (Tukey test; $p<0.05$; Figure 1.0 (a)). The egg clusters took the longest time to hatch under exposure to $100 \mathrm{ppm}$.

One-way ANOVA showed there was a significant difference among tested groups for hatching success (One-way ANOVA; $p<0.05$; Table 1.0). The difference in hatching success was 
insignificant between the control and 25 ppm (Tukey test; $p>0.05$; Figure 1.0 (b)). However, a significant difference was observed between the control and an increase from 50 to $100 \mathrm{ppm}$ (Tukey test; $p$ $<0.05$; Figure 1.0 (b)). No significant difference was found in hatching success with an increase of concentration from 25 to $100 \mathrm{ppm}$ (Tukey test; $p>0.05$; Figure 1.0 (b)). Overall, the result indicates that exposure of $Z$. officinale extract from 50 to $100 \mathrm{ppm}$ has reduced the production of new hatchlings significantly in comparison to the control group.

Table 1. Analysis of one-way ANOVA on the egg hatchability of $P$. canaliculata exposed to $Z$. officinale extract

\begin{tabular}{cccccc}
\hline Source & $d f$ & $S S$ & $M S$ & F-value & P-value \\
\hline a) Hatching time & & & & & \\
Between group & 3 & 450.92 & 150.31 & 24.05 & $0.001^{*}$ \\
$\quad$ Within group & 8 & 50.00 & 6.25 & & \\
$\quad$ Total & 11 & 500.92 & & & \\
& & & & & \\
\hline b) Hatching success & 3 & 1.99 & 0.66 & 6.79 & $0.014^{*}$ \\
Between group & 8 & 0.78 & 0.09 & & \\
$\quad$ Within group & 11 & 2.78 & & & \\
$\quad$ Total & & & & \\
\hline
\end{tabular}

$d f=$ degree of freedom; $S S=$ sum of squares; $M S=$ mean squares

* significant at $p<0.05$
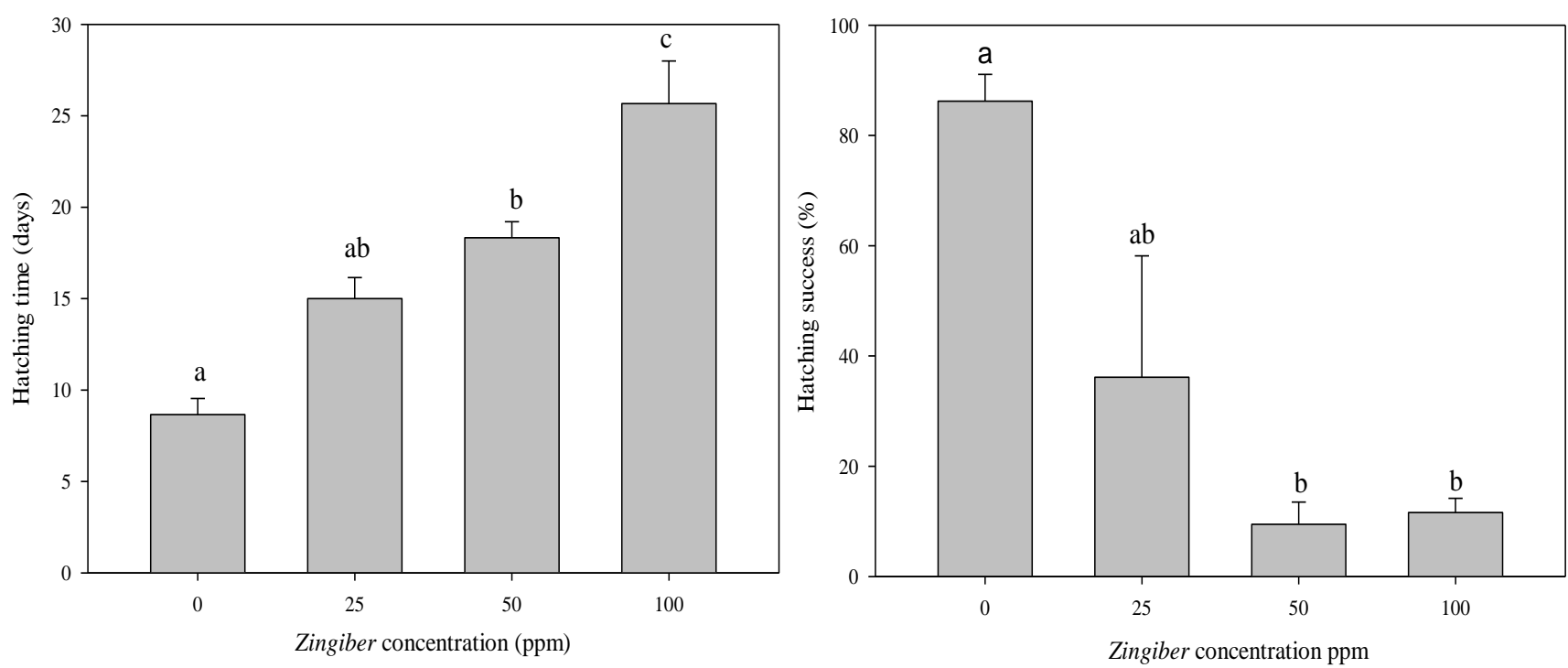

Figure 1. Effect of Z. officinale extract on the (a) hatching time (days) and (b) hatching success (\%) of $P$. canaliculata's egg

\subsection{C. papaya}

The analysis of ANOVA shows that C. papaya extract did not produce any significant effect on the hatching time
(One-way ANOVA; $p>0.05$; Table 2.0). There is no significant difference between the time taken for the eggs to hatch in the control group in comparison to the egg clusters applied with increasing 
concentrations, from 25 to $100 \mathrm{ppm}$, of $C$. papaya extract (Tukey test; $p>0.05$; Figure 2.0 (a)).

The same result is observed on the hatching success of the eggs in exposure to C. papaya extract (One-way ANOVA; $p>$
0.05; Table 2.0). There was no significant difference between the percentage of eggs successfully hatched in the control group and the group of experiments exposed to increasing concentrations, from 25 to 100 ppm, of $C$. papaya extract (Tukey test; $p>$ 0.05; Figure 2.0 (b)).

Table 2. Analysis of one-way ANOVA on the egg hatchability of $P$. canaliculata exposed to C. papaya extract

\begin{tabular}{cccccc}
\hline Source & $d f$ & $S S$ & $M S$ & F-value & $P$-value \\
\hline a) Hatching time & & & & & \\
Between group & 3 & 62.25 & 20.75 & 0.741 & 0.557 \\
$\quad$ Within group & 8 & 224.00 & 28.00 & & \\
$\quad$ Total & 11 & 286.25 & & & \\
& & & & & \\
b) Hatching success & 3 & 300.04 & 100.01 & 0.803 & 0.527 \\
Between group & 8 & 996.86 & 124.61 & & \\
$\quad$ Within group & 11 & 1296.89 & & & \\
$\quad$ Total & 11 & &
\end{tabular}

$d f=$ degree of freedom; $S S=$ sum of squares; $M S=$ mean squares

* significant at $p<0.05$
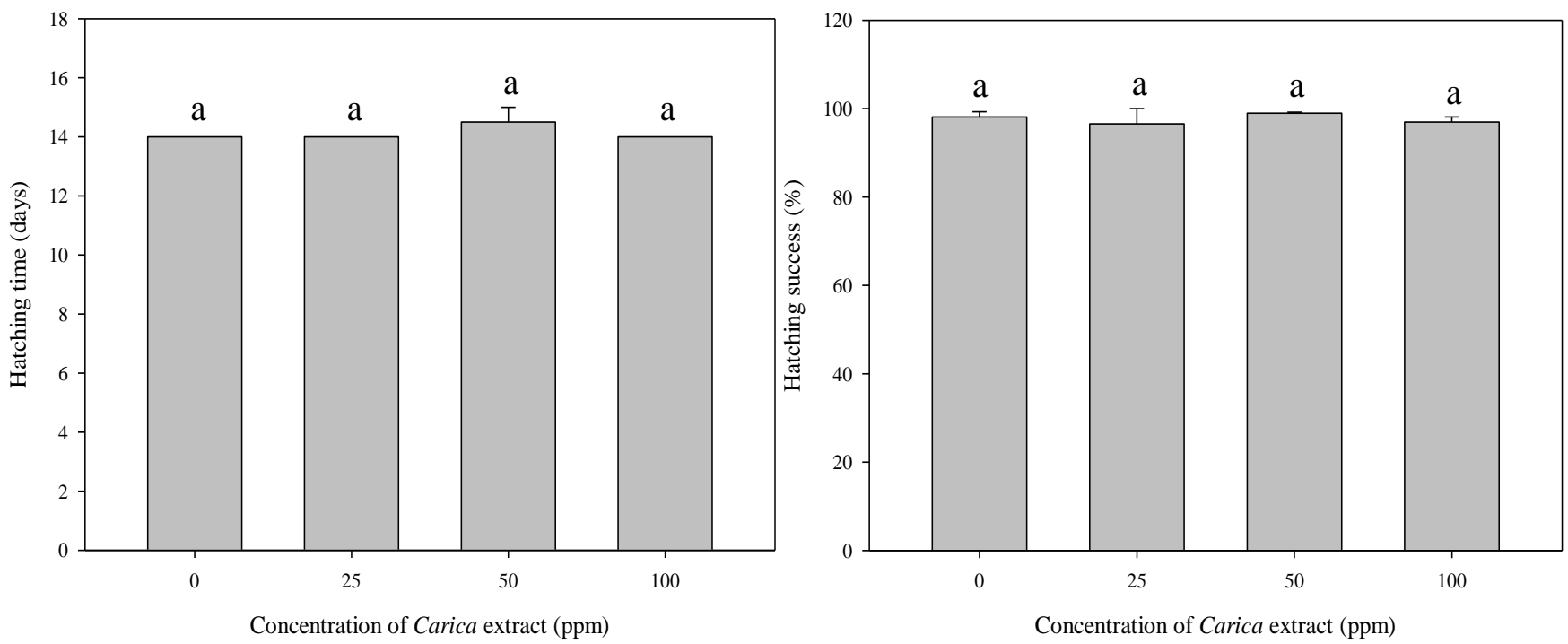

Figure 2. Effect of C. papaya extract on the (a) hatching time (days) and (b) hatching success (\%) of $P$. canaliculata's egg

\section{DISCUSSION}

Biomolluscicides have long been explored as a replacement for synthetic chemical pesticides due to their low toxicity, high biodegradability, and the fact that they do not produce any negative impacts on non-target organisms and 
surrounding ecosystems. Currently, local farmers are still relying heavily on the use of synthetic chemical pesticides due to the fast 'knock-down effect' without any concerns for the adverse effects to the ecosystem, and their own health and safety. Our findings may help in proposing the option to shift to the use of biomolluscicides using available sources that occur abundantly in nature. Finally, this option can add continuous improvement on integrated pest management.

\subsection{Z. officinale}

Our study revealed that the extract of $Z$. officinale produces a strong effect on the hatching time and hatching success of the golden apple snail's eggs. The trend shows that with increasing concentrations of extract ( 25 to $100 \mathrm{ppm}$ ), the eggs hatch later and the number of eggs that successfully hatch decreases significantly. Significant effects were observed above 25 ppm, where hatching success was below $50 \%$ in the clusters of eggs. A study by Prabhakaran et al. (2017) stated that the juvenile apple snail of $P$. maculata was affected by the extract of $Z$. officinale where $50 \%$ of the population died ( $\left.\mathrm{LC}_{50}\right)$ due to exposure of it at a level of 485.48 ppm. Similarly, exposure of Z. officinale to the freshwater snail, Bulinus globosus, revealed that $\mathrm{LC}_{50}$ was achieved at 214.72 ppm (Labe et al., 2012). This indicates that Z. officinale shows molluscicidal activity at higher concentrations during the juvenile stage of $P$. maculata and $B$. globosus. In contrast, a study by Barros Gomes et al. (2019) on the adult stage of the freshwater snail, Biomphalaria glabrata, obtained the $\mathrm{LC}_{50}$ at lower concentrations that were as low as $56.23 \mathrm{ppm}$. In both studies, the molluscicide examination was conducted on the body of snails protected with calcareous shells that were larger in size, and with constant exposure to the $Z$. officinale extract. Our study was on the smaller sized calcareous eggs of the freshwater apple snail, $P$. canaliculata, with single spot spraying. Interestingly, exposure to $Z$. officinale at above $25 \mathrm{ppm}$ demonstrated strong molluscicidal activity when more than $50 \%$ of the $P$. canaliculata's eggs failed to develop and hatch.

Similarly, the role of $Z$. officinale in regulating egg hatchability has been determined in other agricultural pest species. The extract of $Z$. officinale at 0.51 ppm reduced the egg hatchability of the Callosobruchus chinensis (Pulse beetle), the pest insect in the storage of food grains (Chaubey, 2013). Meanwhile, a study by Hamada et al., (2018) found insecticidal properties of $Z$. officinale extract when the egg hatchability of the Spodoptera littoris (Cotton leafworm) was significantly reduced after exposure to it at a level of 40 ppm. In both studies, the pest insects were exposed to $Z$. officinale extract at both larval and adult stages respectively. Interestingly, the adverse effects were continuously seen at the next stage when the affected larva or affected adults began to produce eggs. Exposure to Z. officinale during the larval and adult stages eventually caused physiological disturbances which influenced the rate of egg hatchability in both insects; $C$. chinensis and $S$. littoris.

In other studies, Z. officinale has been observed to cause the decrease in shell thickness in the study on egg characteristics of egg-laying hens (Zomrawi et al., 2014). Since the snail's egg is similarly calcareous (Yang \& Yu, 2019), it is not possible that some amount of $Z$. officinale extract had penetrated the shell and interrupted the embryonic development inside (size of $P$. canaliculata egg $=2.0 \mathrm{~mm}$ ). Overall, the hatching success of the $P$. canaliculata eggs were adversely affected by the application of $Z$. officinale extract regardless of the dosage.

In an extensive phytochemistry study, analysis on the extract of $Z$. 
officinales rhizome revealed the presence of 194 types of volatile oils, 85 types of gingerol, and 28 types of diarylheptanoid compounds (Liu et al., 2019). The most important component is the content of essential oils with major compounds of gingerols and oleoresin. Both compounds give the characteristic of pungency to the $Z$. officinale, and their pharmaceutical properties have long been recognized for their antioxidant, anticancer, antibacterial, antifungal and anti-inflammatory effects. In this study, we provide evidence that the $Z$. officinale extract contains molluscicidal properties, particularly during the egg stage of the $P$. canaliculata. However, the details in the molluscicidal mode of action in altering the egg shell composition and interrupting the embryonic development need further study in the future.

\subsection{C. papaya}

Although not native to Malaysia, $C$. papaya is a perennial species with abundant distribution in this country. They are easily grown in tropical countries as the origin of the tree is from the southern part of tropical Mexico. The motivation of using the $C$. papaya extract in this study is based on their multiple ethnobotanical properties, as reviewed extensively by Srivastava \& Singh (2016). The review reported that many parts of the tree have shown various properties such as anthelmintic, antifungal, antioxidant and anti-fertility properties, and mollusicicidal activity.

The use of $C$. papaya as a biomolluscicide has been reported in previous literature using different parts of the plant. The extract taken from Carica's seed and the latex powder reveal the molluscicidal activity on the adult freshwater snail of Lymnaea acuminata with the $\mathrm{LC}_{50}$ at levels $53.38 \mathrm{ppm}$ (24 hours) and $8.38 \mathrm{ppm}$ (96 hours) respectively (Jaiswal \& Singh, 2008). According to Jaiswal et al. (2008), the toxicity may be due to the presence of the chemical substance, papain. Papain is an enzyme which can be found in all parts of the tree except the root (Islam et al., 2015). This enzyme significantly inhibited the acetylcholinesterase (AChE), acid and alkaline phosphatase (ACP/ALP) activity in the nervous tissue of $L$. acuminata. In addition, the concentration of Carica extract used to kill the population of snails did not affect the non-target fish species, Colisa fasciatus, in the same habitat (Jaiswal \& Singh, 2008).

In contrast, the study on the extract taken from the Carica leaf showed molluscicidal activities at different ranges of concentration depending on the freshwater snail's species. In adult Biomphalaria pfeifferi, the molluscicidal activity was established at $\mathrm{LC}_{50}=2716.3$ ppm which is higher than the molluscicidal activity observed in the population of Bulinus globosus $\left(\mathrm{LC}_{50}=619.1 \mathrm{ppm}\right)$ (Adetunji \& Salawu, 2010). In our study, we used the leaf extract of Carica too, but with much lower concentrations between 20 to $100 \mathrm{ppm}$. As a result, no significant molluscicide effects were observed on the eggs of the $P$. canaliculata. Although in previous studies the experiments on toxicity used adult snails, the results are likely comparable to the use of eggs as in our study. Both adult and egg stages are protected by calcareous shells. In conclusion, we extrapolate that the strong molluscicide effect is more due to the seed and latex powder than the leaf extract. In future, we recommend the use of higher concentrations of Carica's leaf extract to examine the molluscicidal effect on the egg hatchability of $P$. canaliculata.

\section{CONCLUSION}

High dependence on synthetic chemical molluscicides has contributed to undesirable effects on the environment and non-target organisms. Now, the shift to safer techniques to control the pest 
population is highly demanded to secure the biodiversity and sustainability of rice plantations. In this study, we found that the extract of $Z$. officinale rhizome produced stronger molluscicidal activity than the extract of $C$. papaya that was taken from the leaf. The effect of toxicity was observed at concentrations of less than 100 ppm, emphasizing that $Z$. officinale is a strong biomolluscicide, particularly in controlling the egg hatchability of $P$. canaliculata. The egg hatchability is crucial since thousands of new individuals may emerge in environments if no adequate control measures are taken by the farmers and related authorities. In future research, we recommend further toxicity testing is conducted on non-target organisms as well as investigating the mechanism of ginger extract in interrupting the embryonic development of snails.

\section{ACKNOWLEDGEMENT}

The consumables and chemical items for this research were self-sponsored. The authors wish to thank Assistant Science Officer Mohd Hafiz Md Isa, and the students of the Diploma of Science for their kind help and technical assistance during the length of the experiment. We are grateful to the Faculty of Applied Science, Universiti Teknologi MARA Perak Branch, Tapah Campus for their laboratory and equipment facilities.

\section{REFERENCES}

Adetunji, V. O., \& Salawu, O. T. (2010). Efficacy of ethanolic leaf extracts of Carica papaya and Terminalia catappa as molluscicides against the snail intermediate hosts of schistosomiasis. Journal of Medicinal Plants Research, 4(22), 2348-2352. DOI: 10.5897/JMPR10.468.
Arfan, A. G., Muhamad, R., Omar, D., Nor Azwady, A. A., \& Manjeri, G. (2014). Distribution of two Pomacea spp. in rice fields of Peninsular Malaysia. Annual Research \& Review in Biology, 4(24), 4123-4136.

DOI: 10.9734/ARRB/2014/11398.

Barros Gomes, P. R., Fernandes, R. P., Reis, J. B., Fontenele, M. A., de Freitas, A. C., da Silva, J. C., de Oliveira, R. W. S., da Silva Lyra, W., de Paula, M. d. L., Louzeiro, H. C., \& Filho, V. E. M. (2019). Molluscicidal activity of the essential oil of Zingiber officinale roscoe rhizomes. Journal of Essential Oil Bearing Plants, 22(2), 526-534. DOI: 10.1080/0972060X.2019.1611484.

Chaubey, M. K. (2013). Biological activity of Zingiber officinale (Zingiberaceae) and Piper cubeba (Piperaceae) essential oils against pulse beetle, Callosobruchus chinensis (Coleoptera: Bruchidae). Pakistan Journal of Biological Sciences, 16(11), 517-523. DOI: 10.3923/pjbs.2013.517.523.

Demetillo, M. T., Baguio, M. L., Limitares, D. E., Madjos, G. G., \& AbrenicaAdamat, L. R. (2015). Effect of Cymbopogon citratus (lemon grass) crude leaf extracts on the developmental stages of Pomacea canaliculata (Golden apple snail). Advances in Environmental Sciences, 7(3), 460-467.

Doctor, T. (2019). Molluscicidal Performance of Kae Farang (Gliciridia sepium, JacqStrudel and Siam Weed (Chromolaena odorata, Linn.) leaf extracts on Golden snail (Pomacea canaliculata, Linn.) (February 12, 2019). DOI: $10.2139 /$ ssrn.3385950.

Hamada, H. M., Awad, M., El-Hefny, M., Moustafa, M.A.M. (2018). Insecticidal activity of garlic (Allium sativum) and 
ginger (Zingiber officinale) oils on the cotton leafworm, Spodoptera littoralis (Boisd.) (Lepidoptera: Noctuidae). African Entomology, 26(1), 84-94. DOI: 10.4001/003.026.0084.

Islam, A., Al-Mamun, M. A., Parvin, S., Sarker, M., Zaman, M. K., Farhana, P., Shahriar, Z., \& Salah Uddin, M. (2015). Evaluation of antibacterial activities of latex of Caricaceae (Carica papaya L.). Asian Journal of Pharmaceutical and Clinical Research, 8(1), 308-311.

Jaiswal, P., \& Singh, D. K. (2008). Molluscicidal activity of Carica papaya and Areca catechu against the freshwater snail Lymnaea acuminata. Veterinary Parasitology, 152(3-4), 264270. DOI: 10.1016/j.vetpar.2007.12.033.

Jaiswal, P., Singh, V. K., \& Singh, D. K. (2008). Enzyme inhibition by molluscicidal component of Areca catechu and Carica papaya in the nervous tissue of vector snail Lymnaea acuminata. Pesticide Biochemistry and Physiology, 92(3), 164-168. DOI: 10.1016/j.pestbp.2008.07.011.

Labe, Y., Inabo, H. I., \& Yakubu, S. E. (2012). Comparative molluscicidal activity of aqueous and methanolic extracts of Zingiber officinale against Bulinus globosus. Advances in Environmental Biology, 6(2), 831-835. http://www.aensionline.com/aeb/2012/8 31-835.pdf.

Liu, Y., Liu, J., \& Zhang, Y. (2019). Research progress on chemical constituents of Zingiber officinale Roscoe. BioMed Research International, 2019(5370823), 1-21. DOI: $10.1155 / 2019 / 5370823$.

Lowe, S., Browne, M., Boudjelas, S., \& De Poorter, M. (2000). 100 of the world's worst invasive alien species: A selection from the global invasive species database. IUCN Invasive Species Specialist Group.

Mahboubi, M. (2019). Zingiber officinale Rosc. essential oil, a review on its composition and bioactivity. Clinical Phytoscience, 5(6), 1-12. DOI: 10.1186/s40816-018-0097-4.

Mao, Q. Q., Xu, X. Y., Chao, S. Y., Gan, R. Y., Corke, H., Beta, T., \& Li, H-B. (2019). Bioactive compounds and bioactivities of ginger (Zingiber officinale Roscoe). Foods, 8(6), 185. DOI: $10.3390 /$ foods 8060185 .

Marston, A., \& Hostettmann, K. (1985). Review article no. 6: Plant molluscicides. Phytochemistry, 24(4), 639-652. DOI: 10.1016/S00319422(00)84870-0.

Massaguni, R., \& Md Latip, S. N. H. (2012). Neem crude extract as potential biopesticide for controlling golden apple snail, Pomacea canaliculata. Pesticides Advanced Chemical and Botanical Pesticides, 10, 233-254. DOI: $10.5772 / 48626$.

Massaguni, R., \& Md. Latip, S. N. H. (2015). Assessment the molluscicidal properties of azadirachtin against golden apple snail, Pomacea canaliculata. Malaysian Journal of Analytical Sciences, 19(4), 781-789. http://mjas.analis.com.my/wpcontent/uploads/2018/11/Rosdiyani_19 _4_17.pdf.

Mohd Salleh, N. H., Arbain, D., Mohamed Daud, M. Z., Pilus, N., \& Nawi, R. (2012). Distribution and management of Pomacea Canaliculata in the Northern Region of Malaysia: Mini review. Asia-Pacific Chemical, Biological \& Environmental Engineering Society (APCBEE) Procedia, 2(2012), 129-134. DOI: 10.1016/j.apcbee.2012.06.024. 
Musman, M., Kamaruzzaman, S., Karina, S., Rizqi, R., \& Arisca, F. (2013). A preliminary study on the anti-hatching of freshwater golden apple snail Pomacea canaliculata (Gastropoda: Ampullariidae) eggs from Barringtonia racemosa (Magnoliopsida: Lecythidaceae) seeds extract. Aquaculture, Aquarium, Conservation \& Legislation - International Journal of the Bioflux Society, 6, 394-398. http://www.bioflux.com.ro/docs/2013.394 -398.pdf.

Phoong, M. J. C., Hah, H. E., Rao, S. R., Yow, Y. Y., \& Ratnayeke, S. (2018). Invasive apple snails in wetlands of Selangor, Malaysia: Species, distribution, and ecological associations. Journal of Tropical Biology and Conservation, 15, 43-60. https://jurcon.ums.edu.my/ojums/index. php/jtbc/article/view/1474.

Prabhakaran, G., Bhore, S. J., \& Ravichandran, M. (2017). Development and evaluation of poly herbal molluscicidal extracts for control of apple snail (Pomacea maculata). Agriculture, $\quad 7(3), \quad 22 . \quad$ DOI: 10.3390/agriculture7030022.

Priyadarshi, A., \& Ram, B. (2018). A review on pharmacognosy, phytochemistry, and pharmacological activity of Carica papaya (Linn.) leaf. International Journal of Pharmaceutical Sciences and Research, 9(10), 40714078. DOI: 10.13040/IJPSR.09758232.9(10).4071-78.

Ramli, N. H., Yusup, S., Johari, K., \& Abd Rahim, M. (2017). Selection of potential plants for saponin extract using supercritical- $\mathrm{CO}_{2}$ extraction against golden apple snails (Pomacea canaliculata) for paddy cultivation. Archives of Crop Science, 1(1), 30-37. DOI: 10.36959/718/599.
Sisa, M. H., Aspani, F., Massaguni, R., Awang Damit, H., \& Joseph, H. (2016). Inhibition of Egg Hatching of the Golden Apple Snail by Synthetic Molluscicides. In Regional Conference on Science, Technology and Social Sciences (RCSTSS 2014), 463-471. DOI: 10.1007/978-981-10-0534-3_46.

Srivastava, A. K., \& Singh, V. K. (2016). Carica papaya - A herbal medicine. International Journal of Research Studies in Biosciences, 4(11), 19-25. DOI: $10.20431 / 2349-0365.0411004$.

Teo, S. S. (2004). Biology of the golden apple snail, Pomacea canaliculata (Lamarck, 1822), with emphasis on responses to certain environmental conditions in Sabah, Malaysia. Molluscan Research, 24(3), 139-148. DOI: $10.1071 /$ MR04009.

Yahaya, H., Badrulhadza, A., Sivapragasam, A., Nordin, M., Muhamad Hisham, M. N., \& Mirudin, H. (2017). Invasive Apple Snails in Malaysia. In R. C. Joshi, R. H. Cowie, \& L. S. Sebastian (Eds.), Biology and management of invasive apple snails (pp. 169-195). Philippine Rice Research Institute (PhilRice).

Yang, Q. Q., \& Yu, X. P. (2019). A new species of apple snail in the genus Pomacea (Gastropoda: Caenogastropoda: Ampullariidae). Zoological Studies, 58, 13. DOI: 10.6620/ZS.2019.58-13.

Zomrawi, W. B., Abdel-Atti, K. A., Dousa, B. M., Mohammed, K. E., Mahala, A. G., \& Elamin, K. M. (2014). The effect of dietary ginger root powder (Zingiber officinale) on yolk cholesterol and egg characteristic. International Journal of Livestock Research, 4(9), 42-47. DOI: 10.5455/ijlr.20141222062644. 